\title{
The Impact of Road Network on Distribution of Social Amenities: A Case Study of Giwa Local Government Area of Kaduna State
}

\author{
BY \\ FOIN, DAVID NCHOUJI \\ Department of Geography, Ahmadu Bello University, Zaria.
}

\begin{abstract}
The study focused on the effect of roads on the distribution of social amenities in Giwa Local Government Area of Kaduna State. It took a critical look at the road network connectivity and accessibility of the towns in Giwa in an attempt to understanding the level to which these road network components affected the distribution of social infrastructure. The data for this study was derived from secondary sources ; (i)The topology of the routes was extracted from the base map of the local government area, and this took some of the road network component. (ii)The statistical data on social amenities in the Local Government Area came from the various departments in the local government headquarters.
\end{abstract}

A correlation analysis was applied on the data and the results tested for significance. Results of the study showed that the relationship between road network, and node accessibility and the distribution of social amenities, with a correlation coefficient explanation of $36.9 \%$. The high disparity observed in the distribution of social amenities is the result of very poor connectivity index as revealed by the road network in the area.

\section{Introduction}

Hoyle (1977) defines transportation as the movement of people and goods and the facilities used for that purpose. Cresswd (1977) sees transport as the science and art of carrying people, goods and services for money. This is accomplished through various modes of transportation, road, air and water. It is seen essentially as a service which enables people, firms and various entities to carry out their activities at sites selected for those purposes in separate locations

Road transportation is the most common form of transportation in most parts of the world. It gave rise to the emergence of the bicycle and later automobile such as cars and lorries. Among the advantages of road transportation 'are its flexibility and ease of operation. Roads can be easily extended to reach remote places, and it is able to provide door to door services.

The automobile can deliver goods from port to the factory, from the factory to the market, and from the market to the doorstep of the consumer. Furthermore, road transport is easy to operate because it dose not always require a high level of investment. Road are easily created by clearing the vegetation along tracks and motor vehicles are much cheaper than trains or aeroplanes. Motor vehicles also do not require complex controls at the terminals as aircrafts do. Road transportation has been one of the most important factors in the development of the Nigerian economy and society today.

Road transport is indispensable to economic development especially in a developing country like Nigeria. This is because transport is essential to the execution of daily economic and social activities in any given area. (Aloba, 1975). Thus, at any given stage of economic development; a country or region requires a certain level of transport facilities in order to maximize its resources potentialities (Amdi, 1987).

Road transportation in Nigeria has developed greatly over the past hundred years from bush paths to modern carriageways. In Nigeria, for instance, emphasis on transport development has been more on land transportation as revealed in the country's successive national development plans (1975 - 1980), where over $70 \%$ of public expenditure was on land transportation alone.

Similarly, the priorities of some states in the country have been on land transportation. For instance, the 1980 - 85 development plan period of the former Bendel State (now Edo/Delta State) has revealed that $63.7 \%$ of her public expenditure on transportations was allocated to road development.

That not withstanding, what is seen over Nigeria social space today is high disparity in the distribution of social amenities, despite all 
conscious efforts in series of National Development plans to reduce spatial disparities in socio-economic development (Onokerhoraye 1977) such disparities have been pronounced in the distribution of amenities like schools, hospitals and postal service. As expected; the provision of these infrastructure has not kept pace with demand due largely to some constrain in the area of road development. This paper is an attempt to examine as a case study, the relationship between road network development and the distribution of social amenities in Giwa Local Government Area of Kaduna State.

The specific objectives of this study are:

i. To examine the effect of accessibility on the distribution of social amenities available in the area.

ii. To estimate the road. network connectivity of the region and effects on distribution of social amenities.

Based on the above objectives, the hypothesis examined is that: "There is no positive relationship between model accessibility and the distribution of social amenities".

\section{Conceptual Framework}

The theoretical explanations governing the study evolves from graph theory, and central place Nodel. Graph theoretical analysis by Kansky (1963) has turned out to be an appropriate method for understanding, representing and manipulating spatial structures.

Several indices like the Beta (B), Gamma (y) and Alpha (a) combined in the model have been used to measure road network connectivity (Garrison and Marble, 1961; Mystruen and Dacey, 1960). In applying the model, the road network in an area is usually abstracted into a set of nodes (v) (points) and a set of edges (e) (links) connecting the nodes. The information thus derived is used to construct a set of graph - theoretical indices which serves as a standard for comparison of such network with others. (Burton, 1963, Kansky, 1963, James, 1970). The analysis of such road network in various countries has revealed a strong correlation between levels of economic development in those countries and topological connectivity indices (Kansky, 1963).

Accessibility of a place is simply the degree of connection between the place and all other places in transport network (Spate, 1973). The main notion in this case is the ability to get to a given node - the connection component. The binary accessibility matrix introduced into graph theory by Garrison and Ituff (1960) has therefore formed the basis for measuring the connection component of the road network in Giwa Local Government Area. In its application: $A i=\sum \frac{A i j}{1-j} \quad$ Where Aij is binary entry for nodes with all js Aij is sum of the binary entry

The model reveals that the highest $\mathrm{Ai}$ shows the node that is most accessible i.e. the mode that is most connected. The distribution of social infrastructure within an area is intimately bound up with the geographic disparation of the population within the area connected. Thus, the structure of the settlement in the area connected can be explained by some elements in the central place theory developed by Christaller (1966). His postulated hierarchical and spatial arrangement of urban centers within a city system connotes a situation whereby higher order places supply all the goods of lower order places plus a number of higher order goods and services. Although this concept forms the background for the explanation of the distribution of social infrastructure in any settlement, accessibility and connectivity factors will still playa substantial role in the distribution of such facilities (Okafor, 1977).

\section{Methodology of Study}

\section{Data Collection}

Data on road network were generated by extracting from the base map the topology of the routes (Fig 1 b) using the Graphic theory approach (Garrison, 1960). The topological characteristics (accessibility and connectivity) were derived using the accessibility Matrix model of Garrison and Huff (1960) and connectivity index of Kansky (1963) respectively. 


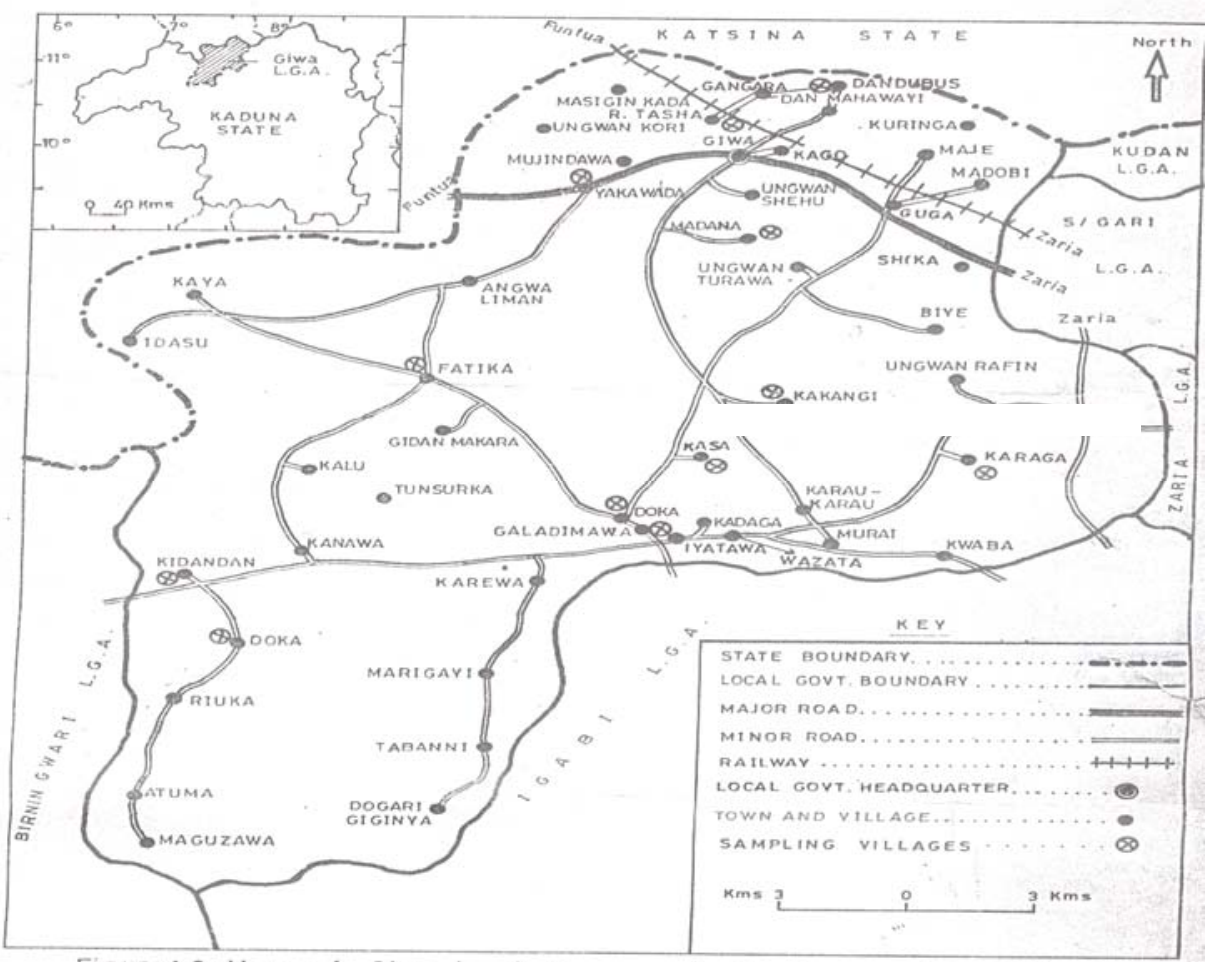

Fig. 1a Giwa Local Government Area Rôad Network

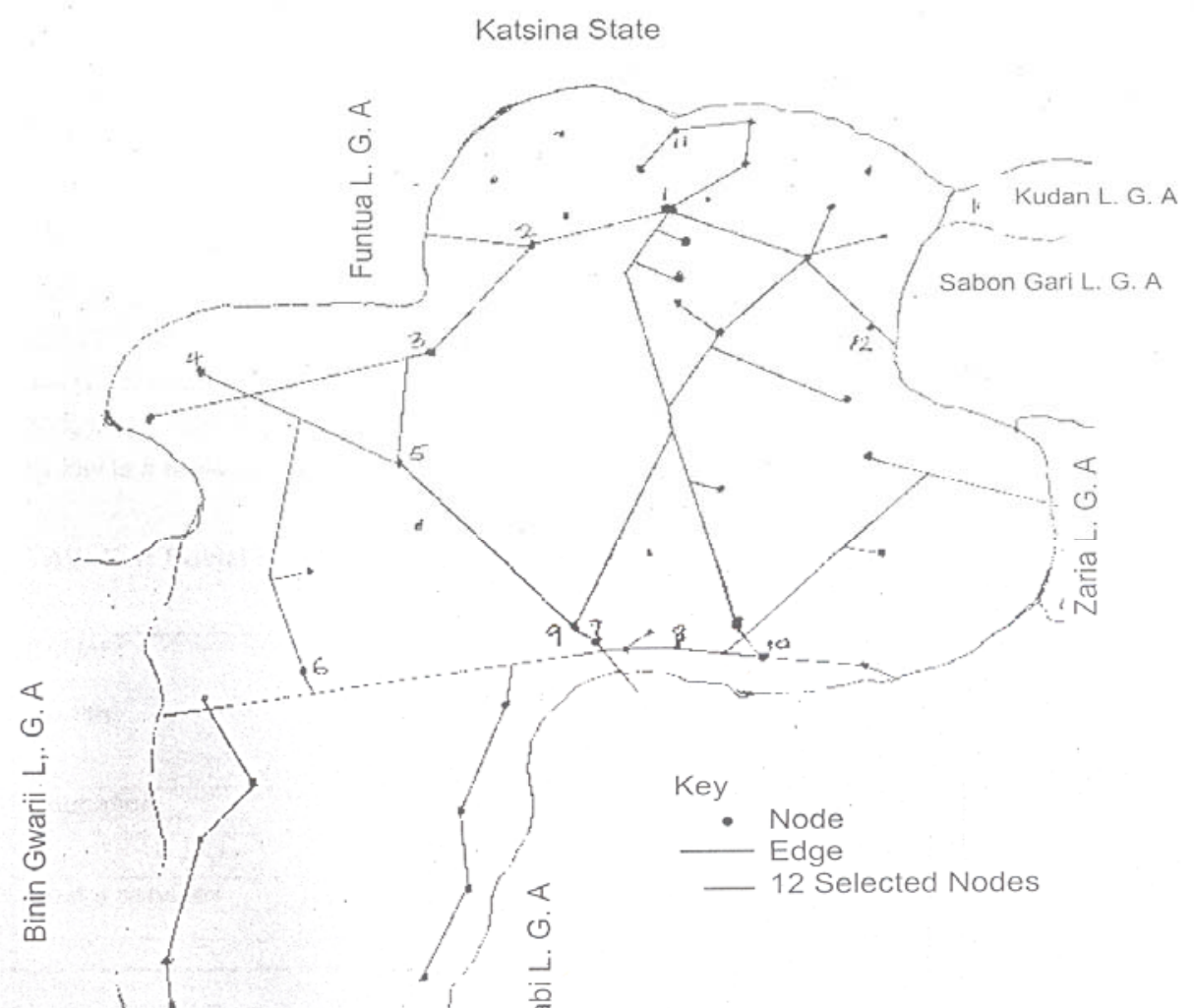

Fig. 1b Graph of the Road Networkin Giwa Local Government Area 
The social amenities considered in the study are the educational amenities (primary, post primary and post secondary schools), Health infrastructure (Hospitals. Maternities) and 'postal amenities (Post Offices and Postal Agencies). Data on educational infrastructure were collected from the Department of Education in the Local Government Headquarters in' Giwa while data on health and postal services were collected from the Local Government Secretariat.

Twelve towns were covered in the study. These Towns were sampled based on their population, urbanization status and accessibility indices. Product moment correlation statistic was adopted in estimating the correlation parameter between the two variables (accessibility and number of amenities. The T-test. Statistic was equally adopted in testing the validity of the parameters returned by the correlation analysis.

Giwa Local Government Area is located between latitude $10^{\prime} 50 \mathrm{~N}$ and 11 ' $^{2} 5^{\prime} \mathrm{N}$ and longitude $7 ' 15^{\prime} \mathrm{E}$ and 7'28E. Fig. 1a. The population estimate as at 1991 was 186,904 people (N.P.C 1991). There are 47 towns/nodes. The total length of roads is $307 \mathrm{~km}$ (Foin, 2001). The road network density is $3 \mathrm{sqkm}$ per grid cell of lend. Only $33 \%$ of the total length of roads was tarred.

\section{Analysis of Road Network Connectivity and Node Accessibility}

The road network in the Giwa Local Government

TABLE 1: Social Amenities in Giwa Local Government Area

TABLE 1: Social Amenities in Giwa Local Government Area
\begin{tabular}{|l|l|l|}
\hline Social & Infrastructure & Total Number \\
\hline Health & Hospital & 2 \\
& Dispensaries & 30 \\
& Materials & 5 \\
\hline Education & Primary & 100 \\
& Post Primary & 14 \\
& Post Secondary & 2 \\
\hline Postal & Postal Agency & 20 \\
& Post Office & 2 \\
\hline & Total & $\mathbf{1 7 5}$ \\
\hline
\end{tabular}

Table 2: $\quad$ Connectivity values of the Road Network and Node Accessibility

\begin{tabular}{|c|c|c|}
\hline Index of Computation (1) & $\begin{array}{l}\text { Index formular and } \\
\text { application (2) }\end{array}$ & Connectivity value (3) \\
\hline Beta (B) & $\mathrm{e}=\frac{37}{47}$ & 0.787 \\
\hline Gamma (Y) & $\frac{\mathrm{e}}{3(\mathrm{v}-2)}=\left(\frac{37}{47-2)}=145^{\frac{37}{}}\right.$ & 0.348 \\
\hline Alpha (a) & $=\begin{array}{l}-9 \\
89\end{array}$ & -0.101 \\
\hline
\end{tabular}

Area was abstracted into a set of nodes (points) and edges. (Links) connecting the nodes (fig. 1b). Based on this, all pairs of relationship between the nodes were enumerated. The information derived was used in constructing a set of graph theoretical as illustrated in table 2. There are 37 edges (e) and 47 nodes (v) in the network. The connectivity values thus derived for the road network using Beta (B), Gamma (Y) and Alpha (a) indices have equally been illustrated in table 2 below.

The Beta (B) indicates the average number of links in and out of a node; this is approximately 1 , as seen in the table. That means that every node on the average is linked with at most one route. By all standards, this connectivity value is low (Kansky, 1963). Thus, that Giwa Local Government Area is not properly connected or linked. The Gamma index, which shows the degree to which the total road network allows direct movement between the various areas, is found to be $0.348 \%$. This reveals the connectivity level and is quite indicative of the level of road development in Giwa Local Government Area. However, the connectivity level revealed by Gamma index could only be said to be true if the roads where all season roads. In Giwa Local Government Area over $60 \%$ of the roads are usually out of use during the rainy season (Foin, 2001) the Alpha (a) index reveals that the road network in the area is below $0 \%$ connectivity. This is very clear: pointer to the under developed nature of the Local Government Area as far as road construction and development is concern. 
Table 3: Accessibility value and No. of social amenities of selected Towns in

Giwa Local Government Area

\begin{tabular}{|l|l|l|l|}
\hline S/N & TOWN & $\begin{array}{l}\text { ACCESSIBILITY } \\
\text { VALUE (X) }\end{array}$ & $\begin{array}{l}\text { TOTAL } \\
\text { INFRASTRUTURE (X) }\end{array}$ \\
\hline 1 & Giwa & 5 & 8 \\
\hline 2 & Yakawada & 6 & 6 \\
\hline 3 & Angwan Liman & 5 & 7 \\
\hline 4 & Kaya & 6 & 9 \\
\hline 5 & Fatika & 6 & 8 \\
\hline 6 & Kanawa & 7 & 5 \\
\hline 7 & Galadimawa & 6 & 12 \\
\hline 8 & Iyatawa & 7 & 7 \\
\hline 9 & Doka & 5 & 4 \\
\hline 10 & Wazata & 8 & 4 \\
\hline 11 & Gangara & 8 & 6 \\
\hline 12 & Shika & 6 & 11 \\
\hline
\end{tabular}

In estimating the accessibility of the nodes for the area, the binary connectivity table by Stutz (1973) was constructed for all the .nodes in the study area. In Stutz's table, unity (1) indicates direct connection while zero (0) indicates no direct connection between the given nodes to the set of all other nodes in the network.

Table 3 (columnx) is the extract of the sampled nodes from the accessibility matrix of the road network of Giwa Local Government Area.

\section{Distribution of Social Amenities.}

In Giwa Local Government Area, lower order social amenities like primary schools and dispensaries are distributed all over the, towns and villages in a hierarchical order. These amenities are however more in higher order settlements than in the lower ones. The higher order social amenities like PostPrimary Schools, Post Offices, Teaching Hospital and General Hospital are concentrated in urban and semi urban areas like Shika, Giwa and Galadimawa. The total number of such amenities in each of the selected towns is presented on table 3(column y).

The high disparity 'in the distribution of social amenities observed raise the question as to whether the pattern of road network present in the area has influenced' the distribution pattern of the amenities observed; and if so to what explanation level ?

\section{Result and Discussion}

The relationship between accessibility of the Nodes so derived from the road network and the distribution of social amenities in the area is examined under the following hypothesis: That there is no positive correlation between accessibility of the Nodes and the distribution of social amenities. A product moment correlation analysis was applied on the data, presented in table 3 in order to measure the correlation coefficient between the two variables accessibility ( $\mathrm{x}$ ) and social amenities (y).the result of the analysis is presented in table 4.

From table 4, the value of 0.61 reveals that the relationship between $\mathrm{x}$ and $\mathrm{y}$ is negative and low. This thus indicates that the less accessibility a node/town is the less likely, other things being equal, the number of social amenities such a town will attract. By implication the analysis reveals that if the towns/nodes in the local government area are less accessible because of inadequate road network, the will attract less social amenities.

The co-official of explanation $\left(\mathrm{r}^{2}\right)$ shows that accessibility alone accounts for $36.9 \%$ of the factors responsible for the distribution of social amenities, while the 'remaining $63.1 \%$ is attributed to other factors like population, urban status, government policies etc.

Table 4: Result of correlation Analysis between accessibility (x) and social amenities

\begin{tabular}{|l|l|l|l|l|l|}
\hline & $\mathrm{R}$ & $\mathrm{r}^{2}$ & $\mathrm{df}$ & $5 \%$ sig. level & Decision \\
\hline Pmcc of $\mathrm{x}$ and $\mathrm{y}$ & 0.608 & 0.369 & 11 & 0.623 & Accept it. \\
\hline
\end{tabular}


However, when a significant test was carried out on the $r$ value produced by the analysis, it was observed that $r$ was significantly low at $1 \%$ level. Based on the results, the alternative hypothesis was rejected in favour of the null hypothesis which admits that there is low positive correlation between the accessibility of nodes and the distribution of social amenities in such towns/nodes.

\section{Summary and Conclusion}

The study has revealed that there is a low correlation between accessibility and the distribution of social amenities.

The level of accessibility and connectivity were found to be low in Giwa Local Government Area. The connectivity ratio was approximately 1 edge to 1 town/node. The general level of connectivity was below $0 \%$. The average population/social amenities ratio is 1202 to 1 .

However such ratio has been found to be higher in settlements that are relatively less accessible. For example, Wazata has a ratio population of social amenities of 1241: 1 . This goes to confirm the correlation between roads and distribution of social amenities in the area of study. From the forgoing and given the low accessibility of the study area, the following recommendations are put forward:

1. The Kaduna State Government should help to open up the remote areas of this local government with road links. The local government council should be entrusted with the responsibility of maintaining such road links.

2. The communities in this local government area should embark on the construction and maintenance of feeder roads, as part of their basic community development effort.

\section{References}

Aloba, O. (1975). "Some Geographical Aspects of Rural Transport Network in Regions; M Phil Thesis, University of Ife; Ife - Ife.

Amadi, B.C. (1987). The Impact of Rural Road Construction on Agricultural Development: An empirical Study of Anambra State of Nigeria; Agricultural System.

Bance. D.W. and Hoefer,' J.N (1979). A Measure of Connectivity For Geographic region, Professional Geographer 2 pp. 362. 270.

Barwell, S. (1971) A Model for Determining Road Investment priorities in Agricultural Undeveloped Areas, East Lakes Geographer. P 60-70.
Briggs (1972) Introducing Transport Network University of London Press. Brown R. J. (1966) Transport and Economic Integration of South America, Washington D.C.

Burton (1963) "Accessibility to North Ontarior. An Application of Graphy Theory to Regional Highway. "Candian Geographer, 59,pp 117-440.

Carn Mark C et (1976), The Economic Analysis of Rural Road Project. World Bank Staff Working Paper No 241.

Christaller, W. (1966), Translated by Baakin C. W. (1966); The Central Place, Southern Germany, New Jersey, Englewood Cliffs.

Development Plan (1980-85): Bendel State Ministry Economic Planning and Statistics; Benin.

Dumble, J.M. et al., (1979): Accessibility Indicators for Transport Planning, "Transportation Research, pp 99- 109.

Federal Ministry of Economic Development (1975). The Third National Development Plan (19751980), vol.11, Lagos.

Foin, D. N. (2001): The Effects of Road Transport Network on Agricultural Produce Marketing. M.Sc Thesis ABU, Zaria.

Ganthier H. L. (1973). The Geography of Transportation New Jersey, Practice - Hall, Inc Englewood Cliffs.

Garrison, W.L and Marble, D.F (1961); Factors Analysis Study of Network Papers, Regional. Science Connectivity of Transportation Association, Vol 12 pp 231 - 238.

Garrison, W.L. and HULL, DZ, (1980), "Structure of Transportation Network", Technical Report, United States Army, Transportation Research Command.

Hagget, P. et al (1990): Network Analysis in Geography; Eward Arnold Ltd London.

Idachaba, F.S. (1986); "Rural Amenities in Nigeria, University Press Ibadan.

Iweka and Rural Urban Agricultural Product Movement" Abraka Journal of Agriculture Vol. 1, No 2. 
James, B. (1971). Functional Regions Within City Centres: A Study of Factors Analysis; Institute of British Geographer, Transaction 49, pp 161 182.

Kansky; K.J. (1963); The Structure of Transport Network; University of Chicago, Department of Geography Research Paper No. 84.

MC Master D.N. (1970) Road Communication and the Pattern of Rural Settlement in Transport in Africa; University of Edinburg Centre of African Studies.

Mosely M. (1979) "Accessibility; the Rural Challenge". Methern and Co. Ltd London.

Mystluen, J.D. and Dacay, F.M. (1960) "A Graph Theoretic Interpretation of Nodal Regions", Papers and Proceedings, Regional Association Vol. Vi, pp 122-137.

Okafor, S.I. (1977), "Location and Utilization of Social Amenities in Etsaaka Local Government Area of Bendle State", Nuj, Vol 20, NO.1.

Ogunduna B. (1972) "The Transport Construction on Rural Development in Nigeria. Proceeding of the 1972 annual Conference of Nigeria Economic Society, Ibadan

Rabinson, E et al (1978), Geography of Transport; MC Donald and Evans, London.

Onakomaiya, D.O (1980): Highway Development a review of Policies in Nigeria, Ibadan University Press.

Onokerkoraye, A. G. (1977). "Transportation in Nigeria National Development, ed by Onakomaiya S.O. et al pp 196-215.

Scott, A.J. (1957); "Programming Model of an Integrated Transportation Network". Paper, Regional Science Association, Vol. 19.

Spate (1973); A Graph Theoretical Approach to' Historical Geography", Professional Geographer 23, pp.5-20

Stutz, S.F. (1973). "Accessibility and the Effect of Sealer Variation on Powered Matrix". Geographical Analysis 5,pp.61 - 66. 